\title{
Prevent Cracking in Deposition of Carbon Steel on Inconel 625
}

\author{
M. A. Morsy ${ }^{1}, M . R$. El Koussy ${ }^{3}$ and M. M. Farag $^{3}$ \\ ${ }^{1}$ Associate professor, Central Metallurgical R\&D Institute CMRDI \\ ${ }^{2}$ Prof, Dept. of Metallurgy, Faculty of Engineering Cairo University \\ ${ }^{3}$ Welding Engineer, Pertojet Company
}

\begin{abstract}
Welding procedure of clad steel including deposition of carbon steel on nickel base alloy usually gives unaccepted mechanical properties. Cracks were formed along type II boundary in nickel base alloy pass and a martensitic layer was formed in carbon steel pass. In this paper, cracks along type II boundary were prevented by lowering the martensitic start temperature $\left(\mathrm{T}_{\mathrm{Ms}}\right)$ of the martensitic layer. Decreasing of $\mathrm{T}_{\mathrm{Ms}}$ was obtained by two methods: Dilution method and Grain refining method. Three levels of $\mathrm{T}_{\mathrm{Ms}}$ (approximately 350,200 , and $50^{\circ} \mathrm{C}$ ) are obtained. The results showed that: cracks along type II boundary were prevented at $\mathrm{T}_{\mathrm{Ms}}$ lower than $200^{\circ} \mathrm{C}$; however type II boundary itself was prevented at $\mathrm{T}_{\mathrm{Ms}}$ lower than $50^{\circ} \mathrm{C}$. Also post weld heat treatment was necessary to achieve accepted impact properties.
\end{abstract}

\section{Introduction}

Welding of carbon steel pipes (X65) cladded by nickel base alloy (Inconel 625) are usually being welded by AWS A5.14- ERNiCrMo3 filler metal. A trial was attempted to weld first and second passes by AWS A5.14- ERNiCrMo3 and subsequent passes by AWS A5.1 E7018. Unaccepted mechanical properties were resulted due to creation of cracks along type II boundary and formation of martensitic layer in carbon steel deposit [1]. In the present paper an unconventional idea was developed to prevent cracking along type II boundary. This idea is illustrated schematically in Fig1, where martensite which formed in carbon steel pass ( $3^{\text {rd }}$ pass) was induced compressive stresses on $2^{\text {nd }}$ inconel pass; hence cracks were prevented. It must be mentioned that the idea of promoting martensitic formation in welds was considered a departure from conventional thinking [2]. But in the present work martensite would be beneficial if lower martensite start temperature was achieved. Lowering martensite start temperature $\left(\mathrm{T}_{\mathrm{Ms}}\right)$ means that more compressive stresses were induced at surrounding passes i.e. transformation induced compressive stresses generation [2-4]. $\mathrm{T}_{\mathrm{Ms}}$ can be controlled by chemical composition and by grain size [5-7].

Two methods were used to reduce $\mathrm{T}_{\mathrm{Ms}}$ of the $3^{\text {rd }}$ pass. The first one was described as "Dilution Method". In this method, dilution level was increased by increasing the welding current. This means that more alloying elements (mainly $\mathrm{Ni}$ and $\mathrm{Cr}$ ) would transfer from the $2^{\text {nd }}$ pass (Inconel) to the $3^{\text {rd }}$ pass (carbon steel).
These alloying elements will increase the hardenability and decrease $\mathrm{T}_{\mathrm{Ms}}$. The second method was described as "Grain Refining Method". In this method $\mathrm{T}_{\mathrm{Ms}}$ decreased by decreasing grain size of the $3^{\text {rd }}$ pass. The composition of the $3^{\text {rd }}$ pass was similar to martensitic stainless steel [1]. Thus, tempering is necessary to provide the required notch toughness [8] The post weld heat treatment (PWHT) was applied for crack free welds.

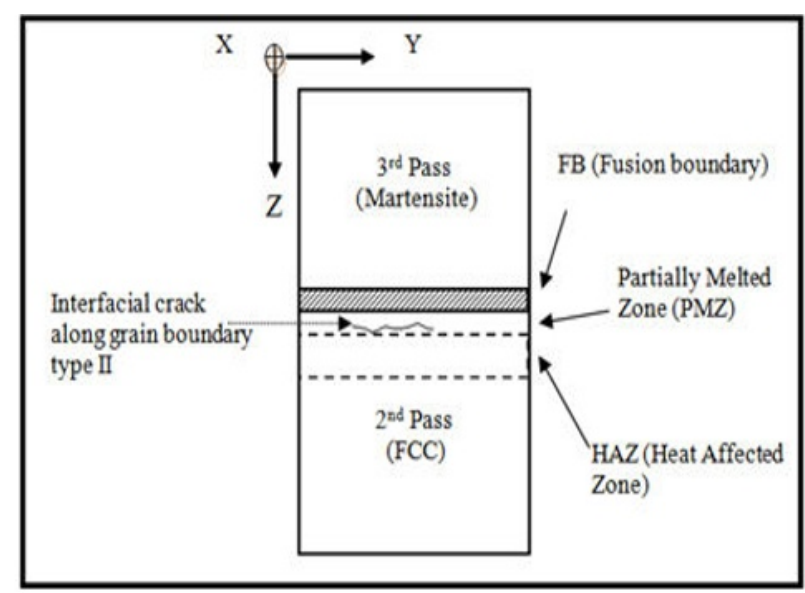

Fig. 1. Schematic diagram illustrated the idea of using martensite which formed in $3^{\text {rd }}$ pass to prevent crack along type II boundary in $2^{\text {nd }}$ pass: " $\mathrm{X}$ " longitudinal, " $\mathrm{Y}$ " transverse and "Z" through thickness 


\section{Experimental Procedures}

\subsection{Welding and Material}

Base metal was API 5L Grade X-65 pipe steel with 305 $\mathrm{mm}$ diameter, $21.4 \mathrm{~mm}$ thickness and cladded with 2 $\mathrm{mm}$ thickness of inconel 625 . Filler metals used in this study were AWS A5.14 ERNiCrMo3 and AWS A5.1E7018. The test coupon pipes were fabricated with full penetration single groove butt joint with 60 degrees included angles. Welding was done using flat position "1G". Gas tungsten arc welding (GTAW) process with pure argon shielding gas was used to weld first and second passes using AWS A5.14- ERNiCrMo3 filler metal. The heat inputs of the 1 st and 2 nd passes were lowered as possible (about $0.9 \mathrm{KJ} / \mathrm{mm}$ ) to minimize dilution.

Two methods were used to weld the $3 \mathrm{rd}$ pass. The first one was described as "Dilution Method". In this method; the 3rd pass was welded by shielded metal arc welding (SMAW) process using AWS A5.1 E7018. Three levels of dilution were achieved by using three levels of heat input (about1.2, 1.4 and $2.0 \mathrm{KJ} / \mathrm{mm}$ ). The increase in heat input levels was obtained by the increase in welding current from $95 \mathrm{~A}$ to $110 \mathrm{~A}$ and $150 \mathrm{~A}$, respectively. The subsequent passes were welded by AWS A5.1 E7018 using the same heat input of the $3^{\text {rd }}$ pass. The second method was described as "Grain Refining Method". In this method, the 3rd pass was welded by flux cored arc welding (FCAW) process using E70T-4 with amperage of 230 A.. The subsequent passes were welded by SMAW using AWS A5.1 E7018 and applying $1.2 \mathrm{~kJ} / \mathrm{mm}$ heat input.

\subsection{Post Weld Heat Treatment}

Tempering was proceeded at $720^{\circ} \mathrm{C}$ and 3 hours holding time. Tempering was applied only for crack free welds

\subsection{Microstructural Characterization}

Specimens were cut and prepared for mechanical tests in accordance with ASME-Section IX , where tensile, impact and bend test are required. The specimens for impact test were prepared from cap and root (including the $3^{\text {rd }}$ pass). Microstructural characterization was performed using optical metallography and scanning electron microscope. Because of the wide range of compositions and microstructures, a number of chemical etchants were used. Nital $(2 \mathrm{~mL} \mathrm{HNO} 3$ and $98 \mathrm{~mL}$ ethanol) was used to reveal martensitic structure; Vilella's reagent $(5 \mathrm{~mL} \mathrm{HCl}, 1$ gram picric acid, and 100 $\mathrm{mL}$ ethanol) was used to reveal grains of martensite. Mixed acids (equal parts of HCL, HNO3, and acetic acids) were used to reveal grain boundaries of nickel base alloy. Microhardness across transition region was measured using diamond pyramid indenter in conjunction with both 10 and 100 gram loads.

\subsection{Determination of Martensite Start Temperature (TMs) for the 3rd Pass}

In this investigation, $\mathrm{T}_{\mathrm{MS}}$ was calculated using empirical equations. For dilution method, Gooch equation (Eq.1) [9] was used. This equation is usually used for martensitic stainless. However, for grain refining method; Lee equation (Eq. 2) [10] was used. This equation considers the effects of chemical composition and austenite grain size on martensite start temperature.

$\mathrm{Ms}\left({ }^{\circ} \mathrm{C}\right)=540-(497 \mathrm{C} \%+6.3 \mathrm{Mn} \%+36.3 \mathrm{Ni} \%+10.8 \mathrm{Cr} \%+46.6 \mathrm{Mo} \%)$

$\mathrm{Ms}\left({ }^{\circ} \mathrm{C}\right)=402-797 \mathrm{C}+14.4 \mathrm{Mn}+15.3 \mathrm{Si}-31.1 \mathrm{Ni}+345.6 \mathrm{Cr}+434.6 \mathrm{Mo}$

$+(59.6 C+3.8 N i-41 C r-53.8 M o) . G$

Where $G$ is the ASTM austenite grain size and elements in weight fraction

Typical EDX detector was used to measure chemical composition of the $3^{\text {rd }}$ pass. But this detector can detect a limited range of $\mathrm{X}$-ray energies so light elements $(\mathrm{Z}<10)$ such as carbon, nitrogen cannot be measured accurately. To overcome this problem; in the present work; estimated complete chemical composition was determined using back calculation methodology as follows:

1. Major alloying elements such as $\mathrm{Fe}, \mathrm{Ni}$ and $\mathrm{Cr}$ were determined by EDX analysis. Then dilution levels of major elements were calculated using Eq. 3 [6].

$\mathrm{D}=\left(\mathrm{C}_{\mathrm{w}}-\mathrm{C}_{\mathrm{f}} /\left(\mathrm{C}_{\mathrm{b}}-\mathrm{C}_{\mathrm{f}}\right)\right.$

Where $D$ is the dilution, $C_{w}, C_{f}$ and $C_{b}$ are the concentration of each element in weld metal, filler metal, and base metal respectively.

2. Average dilution level $\left(\mathrm{D}_{\mathrm{av}}\right)$ of the major alloying elements was determined.

3. Eq.4 was used to calculate the concentrations of other alloying elements

$$
\mathrm{C}_{\mathrm{w}}=\left[\left(\mathrm{C}_{\mathrm{b}}-\mathrm{C}_{\mathrm{f}}\right) * \mathrm{D}_{\mathrm{av}}\right]+\mathrm{C}_{\mathrm{f}}
$$

\section{Results and Discussion}

\subsection{Effect of TMs value on type II grain boundary conditions}

It is accepted that grain boundary type II worked as a weak line which easy cracked $[11,12]$. In the present work martensitic transformation which formed in 3rd pass was used to produce compressive stresses on 2 nd 
pass, hence tensile stresses were reduced and cracks were prevented. Because of elastic modulus increase with decreasing of metal temperature; the amount of compressive stresses generated from martensitic transformation increased with decreasing of TMs [13, $14]$.

Because of quantitative measurements of stresses at type II grain boundary are hard to conduct, a qualitative method was used to give an indication about stress level. This technique was proceeded by observing any cracks near the fusion boundary i.e. observation of cracks means high tensile stresses. Thus an approach of the relation between TMs values of the 3rd pass and stresses level at fusion boundary was built. Depending on this methodology effective levels of TMs were approximately determined as the following:

a. Case I of Dilution Method: heat input was about $1.2 \mathrm{KJ} / \mathrm{mm}$ which gave $6.5 \%$ average dilution. Mechanical properties are shown in Table 1,2 and 3 , where unaccepted results of side bend test and notch impact toughness are noted. Table4 shows that TMs for the fusion zone of the 3rd pass equaled to $354^{\circ} \mathrm{C}$. Fig2 reveals the cracks along type II boundary. This means that at $354^{\circ} \mathrm{C}$; the created compressive stresses were not sufficient to overcome the tensile stresses, hence crack was occurred.

b. Case II of Dilution Method: Heat input was about $1.4 \mathrm{KJ} / \mathrm{mm}$ which gave $13.5 \%$ average dilution.
Mechanical properties are shown in Tables 1, 2 and 3. As shown in Table 4, TMs for the fusion zone of the 3 rd pass equaled to $197^{\circ} \mathrm{C}$. Fig. 3 shows type II grain boundary appeared without any interfacial cracks. This means that at $197^{\circ} \mathrm{C}$, the created compressive stresses were sufficient to overcome the most of tensile stresses and cracks were prevented. This observation reflects the resulted accepted side bend test and improved notch toughness (Table2, and 3 respectively).

c. Case III of Dilution Method: heat input was about $2 \mathrm{KJ} / \mathrm{mm}$; giving $20.22 \%$ average dilution. This heat input is considered relatively high heat. Mechanical properties are shown in Table 1,2 and 3 , where unaccepted results of side bend and notch impact toughness tests are noted. Fig.4 reveals microstructure near fusion boundary where planar solidification region and type II grain boundary are not found i.e. cellular structure continued until fusion boundary. Depending on Nelson et al. work $[15,16]$, the tensile stress which worked as a driving force for type II boundary formation, was nil. Table 4 shows that TMs for fusion zone of the $3 \mathrm{rd}$ pass was $48 \mathrm{oC}$. Based on these results, it can be concluded that: at TMS equal or lower than $48^{\circ} \mathrm{C}$ the generated compressive stresses at fusion boundary were sufficient to overcome all tensile stresses so type II boundary itself disappeared.

Table 1. Tensile test results in as weld conditions

\begin{tabular}{|c|c|c|c|c|}
\hline \multicolumn{2}{|c|}{ Method } & Ultimate Tensile Stress $\left(\mathbf{N} / \mathbf{m m}^{2}\right)$ & Failure Location & Comment \\
\hline \multirow{6}{*}{ Dilution } & \multirow{3}{*}{ Case I } & 641 & W.M & Acceptable \\
\cline { 3 - 5 } & \multirow{2}{*}{ Case II } & 669 & W.M & Acceptable \\
\cline { 3 - 5 } & \multirow{2}{*}{ Case III } & 645.33 & W.M & Acceptable \\
\cline { 3 - 5 } & 656.6 & W.M & Acceptable \\
\cline { 2 - 5 } & 649.74 & W.M & Acceptable \\
\hline \multirow{2}{*}{ Grain Refining } & 669.34 & W.M & Acceptable \\
\cline { 2 - 5 } & 668.36 & W.M & Acceptable \\
\hline
\end{tabular}

Table 2. Guided side bend test results in as weld conditions

\begin{tabular}{|c|c|c|c|c|}
\hline \multirow{2}{*}{ Specimen No. } & \multicolumn{3}{|c|}{ Dilution Method } & \multirow{2}{*}{ Grain Refining Method } \\
\cline { 2 - 4 } & Case I & Case II & Case III & Accepted \\
\hline $\mathbf{1}$ & Rejected & Accepted & Rejected & Accepted \\
\hline $\mathbf{2}$ & Rejected & Accepted & Rejected & Accepted \\
\hline $\mathbf{3}$ & Rejected & Accepted & Rejected & Accepted \\
\hline $\mathbf{4}$ & Rejected & Accepted & Rejected & Acced \\
\hline
\end{tabular}


Table 3. Notch impact toughness results (Joule) at $0^{\circ} \mathrm{C}$ for as welded conditions

\begin{tabular}{|c|c|c|c|c|c|c|c|c|c|c|c|c|}
\hline \multirow{2}{*}{ Position } & \multicolumn{3}{|c|}{$W M$} & \multicolumn{3}{|c|}{$F L$} & \multicolumn{3}{|c|}{$F L+2$} & \multicolumn{3}{|c|}{$F L+5$} \\
\hline & 1 & 2 & 3 & $\mathbf{1}$ & 2 & 3 & 1 & 2 & 3 & $\mathbf{1}$ & 2 & 3 \\
\hline \multicolumn{13}{|c|}{ Dilution Method } \\
\hline \multicolumn{13}{|c|}{ Case I } \\
\hline Cap & 69 & 60 & 94 & 110 & 50 & 65 & 140 & 115 & 125 & 118 & 117 & 106 \\
\hline Root & $\underline{10}$ & $\underline{12}$ & $\underline{10}$ & 95 & 110 & 85 & 140 & 145 & 150 & 165 & 160 & 155 \\
\hline \multicolumn{13}{|c|}{ Case II } \\
\hline Cap & 64 & 55 & 89 & 105 & 45 & 60 & 135 & 110 & 120 & 113 & 112 & 101 \\
\hline Root & $\underline{19}$ & $\underline{23}$ & $\underline{23}$ & 91 & 106 & 81 & 136 & 141 & 146 & 161 & 156 & 151 \\
\hline \multicolumn{13}{|c|}{ Case III } \\
\hline Cap & 52 & 43 & 77 & 93 & 33 & 48 & 123 & 98 & 108 & 101 & 100 & 89 \\
\hline Root & $\underline{9}$ & $\underline{11}$ & $\underline{13}$ & 78 & 93 & 68 & 123 & 128 & 133 & 148 & 143 & 138 \\
\hline \multicolumn{13}{|c|}{ Grain Refining Method } \\
\hline Cap & 100 & 53 & 86 & 130 & 105 & 109 & 105 & 97 & 96 & 70 & 79 & 103 \\
\hline Root & $\underline{23}$ & $\underline{26}$ & $\underline{22}$ & 92 & 90 & 76 & 127 & 143 & 141 & 150 & 148 & 144 \\
\hline
\end{tabular}

*WM: weld metal * FL: Fusion Line *FL+2: Fusion Line+2mm *FL+5: Fusion Line $+5 \mathrm{~mm}$

However, a plan view of 2 nd pass is illustrated in Fig.5, where parts from filler metal are observed. Parts from filler metals were forced inside the $2^{\text {nd }}$ Inconel pass and solidified giving martensitic islands. Micro-hardness of these regions was ranged from 497 to $522 \mathrm{HV}$. These results are supported by SEM and EDX analyses in Fig.6 where iron percentage was about $92 \%$. These islands were obtained as a result of using high welding current $[17,18]$. As shown in Fig.7 cracked type II boundary is observed parallel to theses filler metal islands. As shown in Table 4, TMs of martensitic islands within 2nd pass is $310^{\circ} \mathrm{C}$. This means that: at $310^{\circ} \mathrm{C}$ compressive stresses were very low compared with tensile stresses so cracking occurred.

Although type II boundary near fusion boundary were prevented, formation of filler metal martensitic islands with cracks within 2nd Inconel pass leaded to poor impact toughness and unaccepted side bend results. These results are given in Table2 and Table3 respectively.

Table 4. Chemical analyses of base metal, filler metal and estimated chemical analyses and $\mathrm{T}_{\mathrm{Ms}}$ of the weld metal

\begin{tabular}{|c|c|c|c|c|c|c|c|c|c|}
\hline \multirow{3}{*}{$\begin{array}{l}\text { Element } \\
(\%)\end{array}$} & \multirow{3}{*}{$\begin{array}{c}\text { Base } \\
\text { Metal } \\
\text { X65 }\end{array}$} & \multicolumn{3}{|c|}{ Filler Metals } & \multicolumn{4}{|c|}{ Dilution Method } & \multirow{3}{*}{$\begin{array}{l}\text { Grain } \\
\text { Refined } \\
\text { Method }\end{array}$} \\
\hline & & \multirow{2}{*}{$\begin{array}{c}\text { AWS A5.1 } \\
\text { E7018 }\end{array}$} & \multirow{2}{*}{$\begin{array}{l}\text { AWS A5.14- } \\
\text { ERNiCrMo3 }\end{array}$} & \multirow{2}{*}{ E70T-4 } & \multirow{2}{*}{ Case I } & \multirow{2}{*}{ Case II } & \multicolumn{2}{|c|}{ Case III } & \\
\hline & & & & & & & WM & Islands & \\
\hline $\mathrm{Ni}$ & 0.011 & 0.03 & 64.6 & 0.02 & 3.02 & 6.32 & 9.46 & 3.94 & 4.72 \\
\hline $\mathrm{Cr}$ & 0.011 & 0.00 & 21.7 & 0.00 & 1.12 & 2.29 & 3.42 & 1.46 & 1.74 \\
\hline $\mathrm{Fe}$ & Bal. & Bal. & 0.6 & Bal. & 93.44 & 88.28 & 83.32 & 91.95 & 89.94 \\
\hline Mo & 0.228 & 0.15 & 8.9 & 0.00 & 0.47 & 0.97 & 1.46 & 0.6 & 0.73 \\
\hline $\mathrm{Nb}$ & 0.008 & 0.00 & 3.5 & 0.00 & 0.21 & 0.43 & 0.65 & 0.27 & 0.32 \\
\hline $\mathrm{C}$ & 0.007 & 0.07 & 0.08 & 0.23 & 0.07 & 0.07 & 0.08 & 0.07 & 0.22 \\
\hline $\mathrm{Mn}$ & 1.4 & 1.05 & 0.00 & 0.5 & 1.02 & 1.00 & 0.97 & 1.02 & 0.52 \\
\hline $\mathrm{Si}$ & 0.22 & 0.55 & 0.1 & 0.28 & 0.55 & 0.54 & 0.54 & 0.55 & 0.30 \\
\hline $\mathrm{P}$ & 0.01 & 0.016 & 0.00 & 0.011 & 0.02 & 0.02 & 0.02 & 0.02 & 0.03 \\
\hline$S$ & 0.005 & 0.01 & 0.00 & 0.003 & 0.01 & 0.01 & 0.01 & 0.01 & 0.01 \\
\hline$\overline{\mathrm{Al}}$ & 0.008 & 0.01 & 0.00 & 1.5 & 0.02 & 0.04 & 0.06 & 0.03 & 1.38 \\
\hline $\mathrm{Ti}$ & 0.1 & 0.001 & 0.00 & 0.01 & 0.02 & 0.04 & 0.06 & 0.03 & 0.04 \\
\hline $\mathrm{Co}$ & 0.00 & 0.00 & 1.00 & 0.00 & 0.05 & 0.11 & 0.16 & 0.07 & 0.08 \\
\hline \multicolumn{5}{|c|}{$\mathbf{T}_{\mathrm{MS}}{ }^{\circ} \mathrm{C}$} & 354 & 197 & 48 & 310 & 56 \\
\hline
\end{tabular}




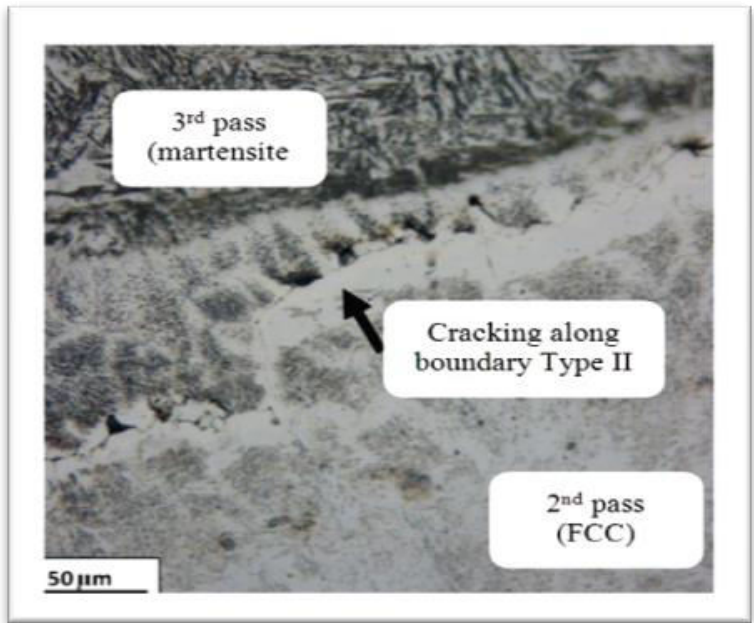

Fig. 2 Case I of dilution method: Interfacial cracks are running along grain boundary type II.

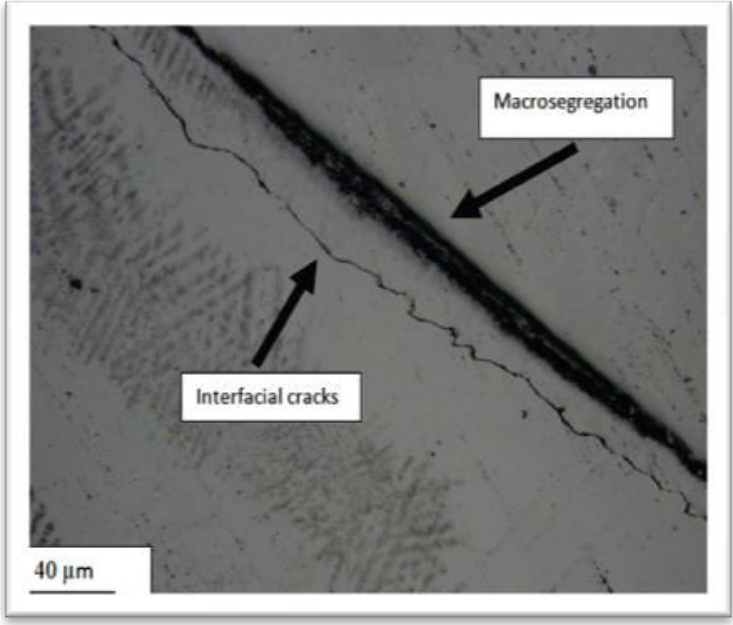

Fig. 4. Case III of dilution method: Parts from filler are forces inside the 2 nd pass forming martensitic island inside with cracks

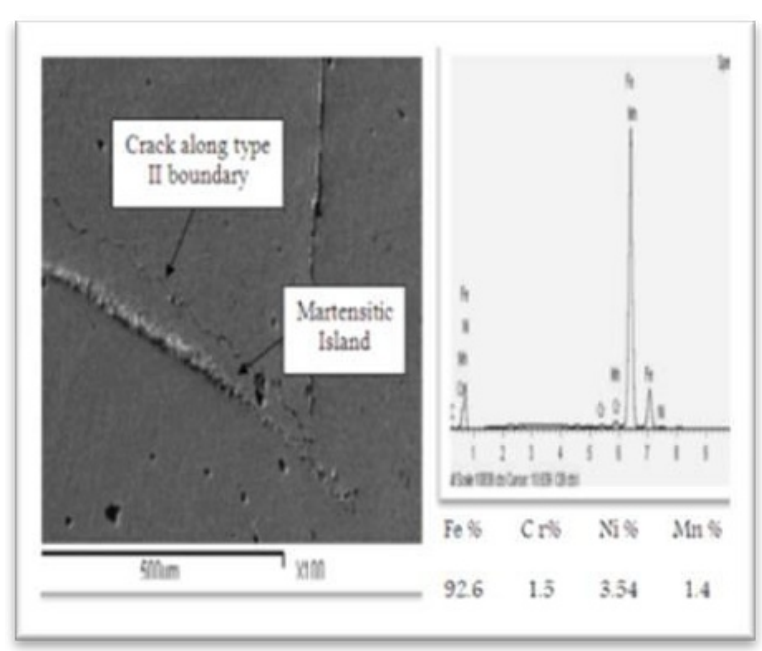

Fig. 6. Case III of dilution method - SEM and EDX for filler metal islands within the $2^{\text {nd }}$ Inconel pass

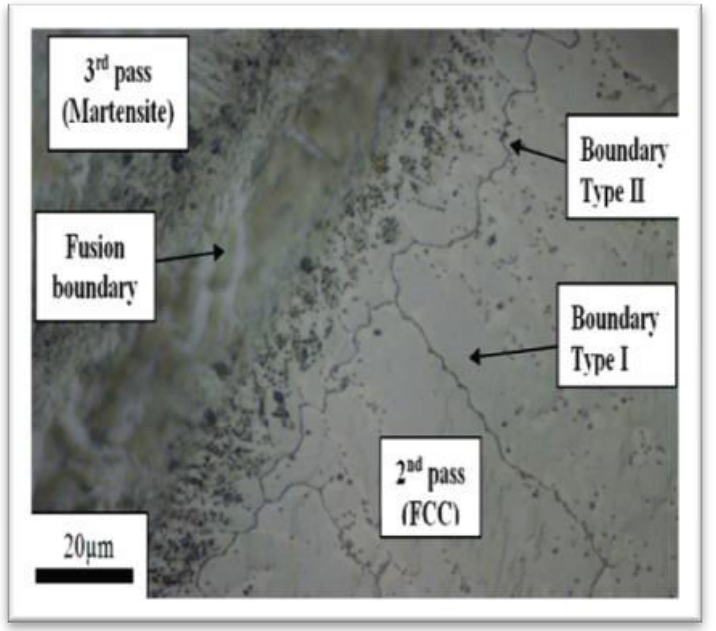

Fig. 3. Case II of dilution method: Grain boundary type II appeared without cracks

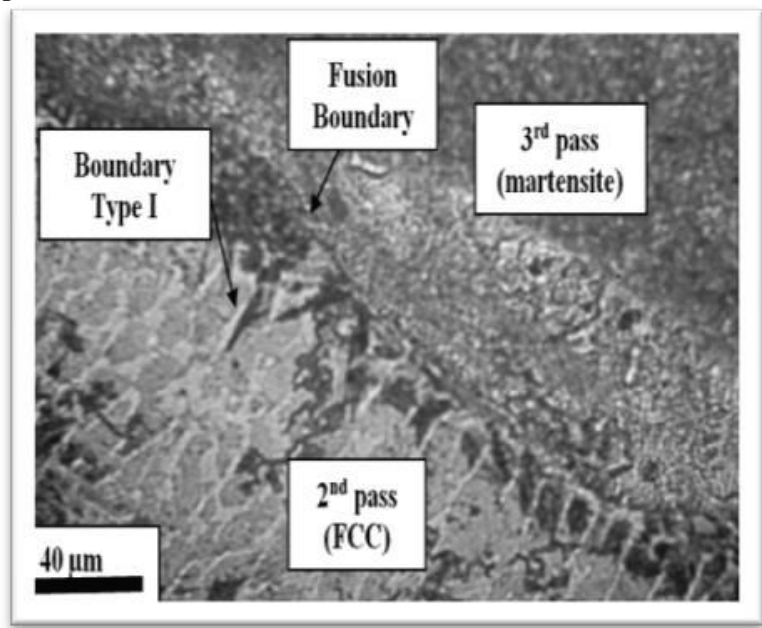

Fig. 5. Case III of dilution method: Type II boundary disappeared and cellular structure continued until fusion boundary

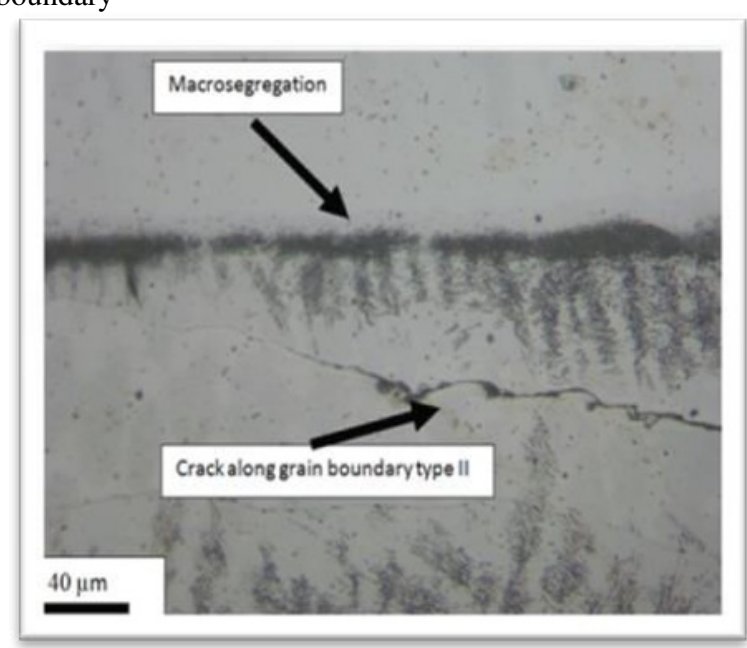

Fig. 7. Case III of dilution method-cracked type II boundary parallel to filler metal islands within the $2^{\text {nd }}$ Inconel pass 


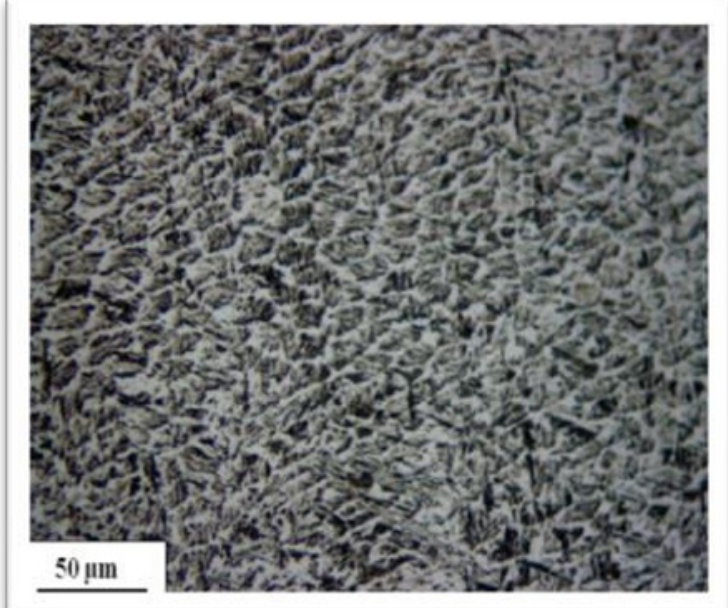

Fig.8. Grain Refinement method - Prior austenite grains of $3^{\text {rd }}$ pass; etched with Vilella's reagent

a) Grain Refining Method: The effect of austenitic grain size on $\mathrm{T}_{\mathrm{Ms}}$ was studied by several researchers [19- 21]. One argument is that a refinement of the austenite grain size leads to the Hall-Petch strengthening of austenite, thereby making it difficult for martensite to form [22]. Grain refinement of the $3^{\text {rd }}$ pass was achieved by using E70T-4 which acted as a source of aluminum oxide and aluminum nitride. Aluminum nitrides and aluminum oxides which may be considered as non-metallic inclusions and impair mechanical properties were used here as nucleation sites causing grain refining. Fig. 8 shows the prior austenite grains of the $3^{\text {rd }}$ pass which is martensite. Grain size was measured using intercept Method -ASTM E112 giving ASTM grain size number equals to12.

As shown in Table 4, $\mathrm{T}_{\mathrm{Ms}}$ of the $3^{\text {rd }}$ pass is $56^{\circ} \mathrm{C}$, which was calculated using Lee equation. Fig. 9 shows that planer solidification region and type II grain boundary are disappeared where cellular structure is continued until

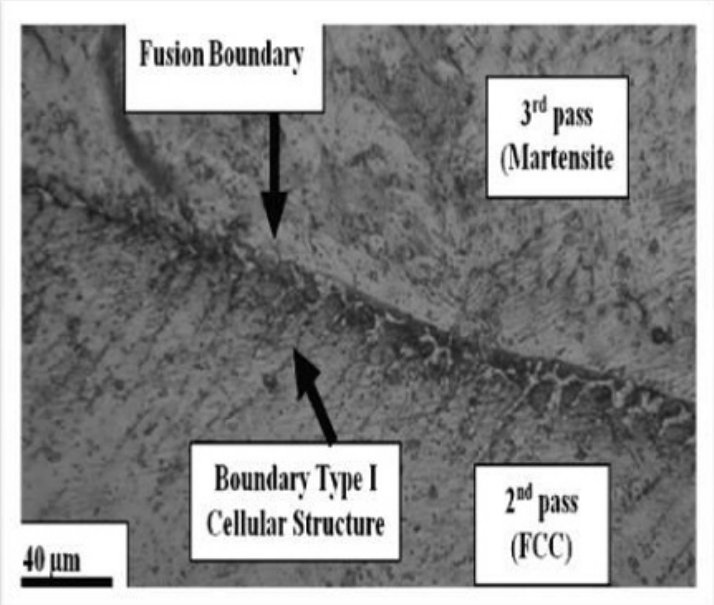

Fig. 9. Grain refining method: Type II boundary disappeared and cellular structure continued until fusion boundary

fusion boundary. This means that: at $56^{\circ} \mathrm{C}$ compressive stresses created at fusion boundary were sufficient to overcome all tensile stresses so type II boundary itself disappeared. Preventing formation of type II boundary was reflected on mechanical properties of weld metal, where accepted side bend test results and improved notch toughness $\left(23\right.$ Joule $0^{\circ} \mathrm{C}$ ) are noted in Table 2 and Table3 respectively.

\subsection{Effect of Post Weld Heat Treatment}

It is well known that the accepted notch toughness of carbon steel at $0^{\circ} \mathrm{C}$ is 27 Joule [22]. However, in the as welded conditions, unaccepted notch toughness at $0^{\circ} \mathrm{C}$ was resulted as shown in Table1. Thus in order to obtain accepted notch toughness, tempering was necessary. Tempering was proceeded at $720^{\circ} \mathrm{C}$ for $3 \mathrm{hr}$ holding time. Based on the results taken from as welded conditions, tempering was applied only for crack free cases (case II of dilution method and grain refining method). The results of mechanical properties are represented in Table 5.

Table 5. Average results of mechanical properties for increased dilution case II and grain refined methods in as weld and tempered conditions

\begin{tabular}{|c|c|c|c|}
\hline Method & $\begin{array}{c}\text { Ultimate Unit Stress } \\
\left(\mathbf{N} / \mathbf{m m}^{2}\right)\end{array}$ & $\begin{array}{c}\text { Side } \\
\text { Bend }\end{array}$ & $\begin{array}{c}\text { Impact Toughness at Root } \\
\text { (including interface } \begin{array}{c}\text { between 2 } \\
\left.\text { at } \mathbf{0}^{\mathbf{0}} \mathbf{C}\right)\end{array}\end{array}$ \\
\hline \multicolumn{4}{|c|}{ And 3 $\mathbf{3}^{\text {rd }}$ Pass) (Joule } \\
\hline $\begin{array}{c}\text { Increased } \\
\text { Dilution }\end{array}$ & 654 & Accepted & 22 \\
\hline $\begin{array}{c}\text { Grain } \\
\text { Refining }\end{array}$ & 680 & Accepted & 23 \\
\hline \multicolumn{5}{|c|}{ As tempered condition } \\
\hline $\begin{array}{c}\text { Increased } \\
\text { Dilution }\end{array}$ & 649 & Accepted & 43 \\
\hline $\begin{array}{c}\text { Grain } \\
\text { Refining }\end{array}$ & 663 & Accepted & 30 \\
\hline
\end{tabular}


Fig.10a and Fig.11a give a plan view for fusion boundary between 2 nd and 3rd pass for case II dilution and grain refined methods respectively. Tempered martensite was noted in the 3rd pass and dark etched region was found at the interface between 2 nd pass inconel and 3rd pass (martensite). Micro hardness was illustrated in Fig. 10b and Fig. 11b where highly localized hardness peak was noted. As documented in literatures [23-26], this dark layer was enriched carbide layer which formed due to carbon migration from ferrite side to austenite side. This layer was clearly observed in grain

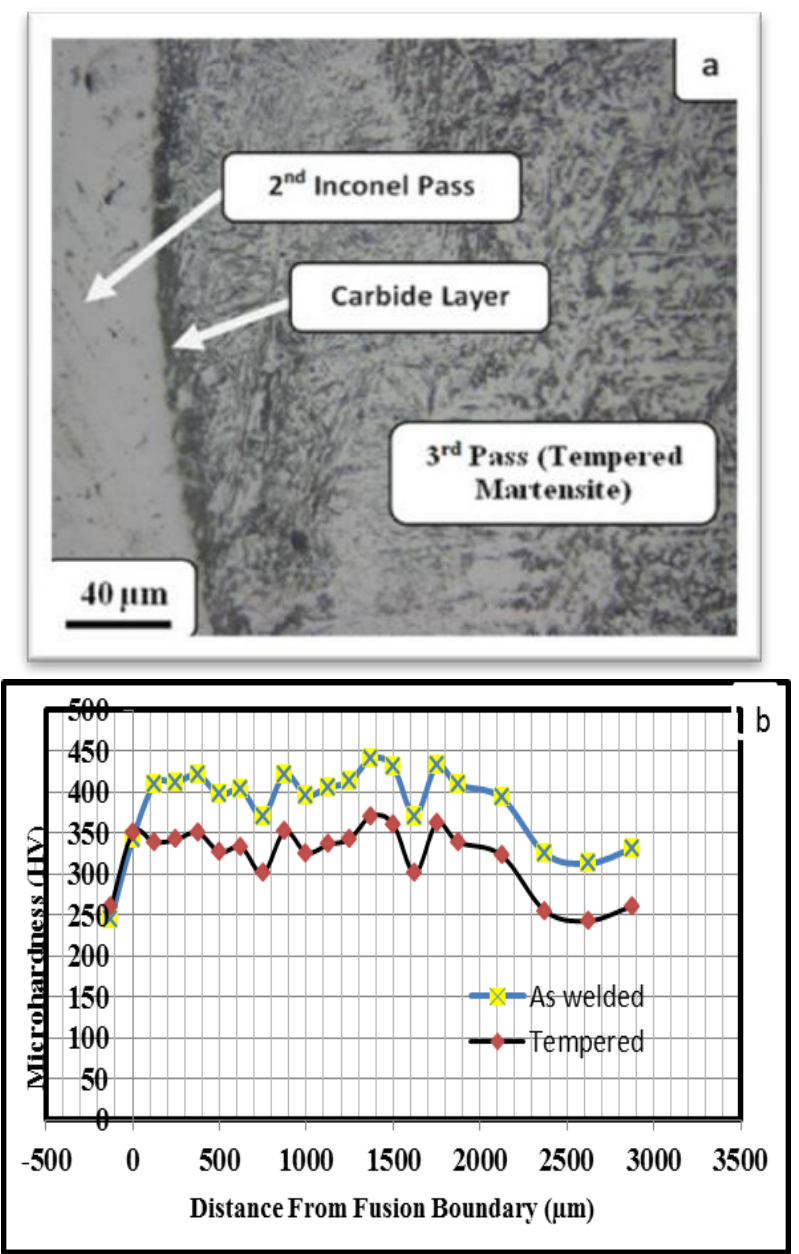

Fig. 10. Case II of Dilution Method

a)- Microstructure b)- Micro hardness

\section{Conclusions}

Based on the results and discussion presented in this investigation, TMs of the 3rd pass was considered the controlling factor that determines the conditions of stresses at type II boundary. Three levels of TMS of the 3rd pass can be obtained:

At $\mathrm{TMs} \geq 300^{\circ} \mathrm{C}$, lower compressive stresses are generated from martensitic transformation in the $3 \mathrm{rd}$ pass. So, high tensile stresses are residue causing cracking along type II boundary.

At $\mathrm{TMs} \approx 200^{\circ} \mathrm{C}$, relatively high compressive stresses are generated from martensitic transformation in the $3 \mathrm{rd}$ refining method than dilution method due to difference of carbon content $(0.22 \%$ and $0.07 \%$ respectively). The effect of this layer on notch toughness is also noted in Table 5. For case II of dilution method; notch toughness increased from 22 to 43Joule (as welded and tempered condition respectively). However for grain refining method notch toughness increased only from 23 to 30Joule (as welded and tempered condition respectively).
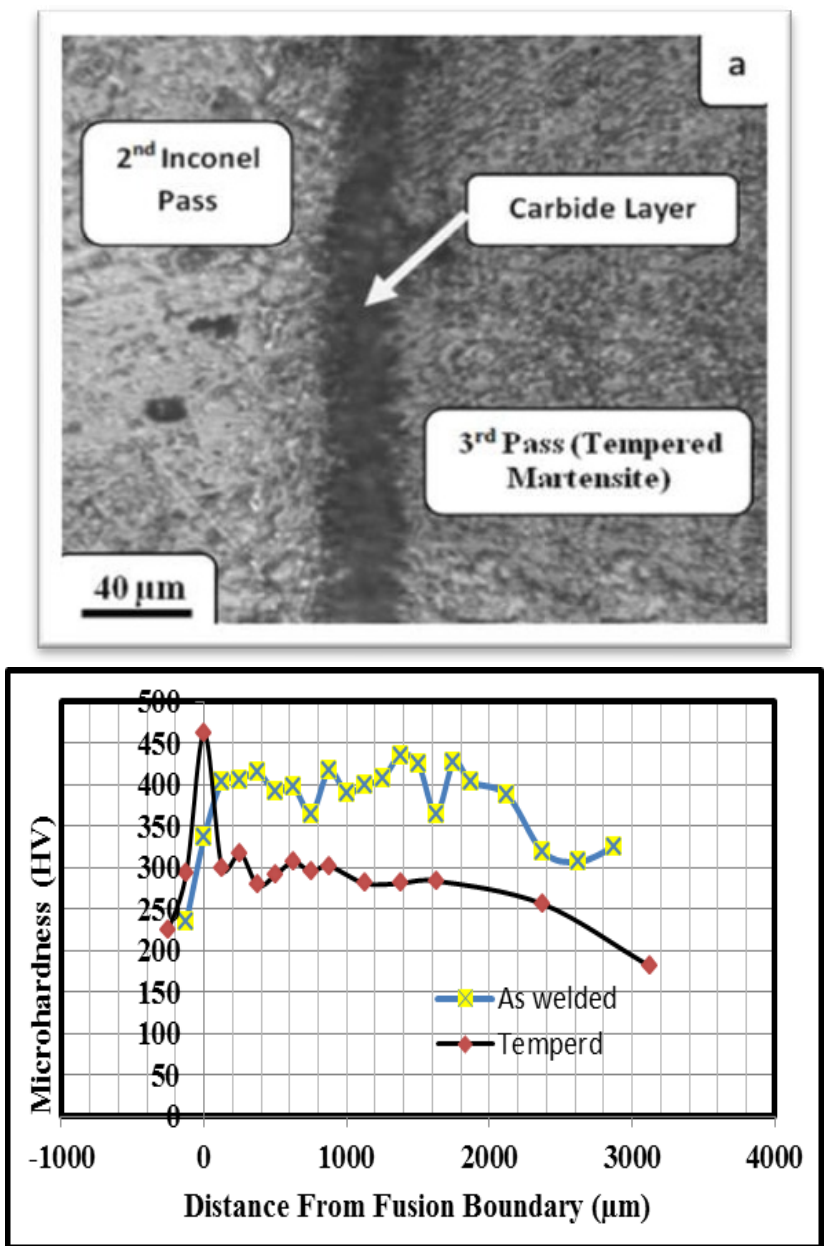

Fig. 11. Grain refining Method

a)- Microstructure b)- Micro hardness

pass. The net stresses which resulted at fusion boundary are tensile but with low magnitude value. These low tensile stresses work as a driving force for type II boundary formation and are not sufficient to cause cracking.

At $\mathrm{TMs} \approx 50^{\circ} \mathrm{C}$, high compressive stresses are generated from martensitic transformation in the $3 \mathrm{rd}$ pass. In this case, all tensile stresses are compensated. Therefore the driving force for formation of type II boundary is nil hence, type II boundary itself is not created.

PWHT is necessary to achieve accepted impact strength (i.e. higher than 27Joule at $0^{\circ} \mathrm{C}$ ). Thus mechanical 
properties are accepted only when cracks are inhibited and PWHT is applied.

\section{References}

1. Winker, Lng. "International Course of Welding Engineer; part 1: Welding process and equipment". Institute in the Germany Welding Socity.P398.(2003).

2. ASM Handbook Committee. "Effect of Transformations on Transient Weld Stresses, Section: Fundamentals of Welding; Volume 6 of Welding, Brazing, and Soldering". Electronic copy of ASM Handbook. (1999).

3. Payares-Asprino, M., Katsumoto, H, and Liu, S. "Effect of Martensite Start and Finish Temperature on Residual Stress Development in Structural Steel Welds" Welding Journal, Vol. 87. P279- 289. (2008).

4. Henrik Alberg., "Simulation of Welding and Heat Treatment Modelling and Validation". Ph.D, Division of Computer Aided Design Department of Applied Physics and Mechanical Engineering; Lulea University of Technology. Sweden. (2005).

5. Seok-Jae Lee and Chester J. Van Tyne." Kinetics Model for Martensite Transformation in Plain Carbon and Low-Alloyed Steels". Volume 43A of Metallurgical and Materials Transactions. P422-427. (2010).

6. Seok-Jae Lee and Young-Kook Lee." Finite Element Simulation of Quench Distortion in a LowAlloy Steel Incorporating Transformation Kinetics" .Elsevier Ltd. Acta Materialia 56 (2008). P 14821490. (2007).

7. Capdevila, C., Caballero, F. García de Andrés, C."Dependence of Martensite Start Temperature on Fine Austenite Grain Size". Madrid, Spain. Material Research Group; Department of Physical Metallurgy. http://www.cenim.csic.es (accessed at 3/12/2012)

8. ASM Handbook Committee. "Selection of Wrought Martensitic Stainless Steels; Volume 6 of Welding, Brazing, and Soldering". Electronic copy of ASM Handbook. (1999).

9. Dupont, J. and Kusko, C. "Technical Note: Martensite Formation in Austenitic/Ferritic Dissimilar Alloy Welds". Welding Journal. P51-56. (2007).

10. Amir Malakizadi. "Simulation of Cooling Behavior and Microstructure Development of PM Steels". Diploma work No. 42/2010 Department of Materials and Manufacturing technology Chalmers University of Technology. Gothenburg, Sweden. Gothenburg. P9-10.(2010).

11. Abdullah, M., and Mohammed, A."Environmental Cracking of Dissimilar Metal Welds". Saudi Aramco Journal of Technology. P1-2. (2008).
12. Rowe, M., Nelson, T. and Lippold, J. "HydrogenInduced Cracking along the Fusion Boundary of Dissimilar Metal Welds". Welding Journal Supplement, P31-37(1999).

13. Eslam Ranjbarnodeh and Mehdi Farajpour."Evolution of Plastic Strains in Dissimilar Weld of Stainless Steel to Carbon Steel" Association of Metallurgical Engineers of Serbia (AMES). P23. (2011).

14. Sindhu Thomas. "Analysis of Low Transformation Temperature Welding (LTTW) ConsumablesDistortion Control and Evolution of Residual Stresses". M.S., Faculty and Board of Trustees of the Colorado School of Mines.P13-15. (2013).

15. Nelson, T., Lippold, J. and Mills, M. "Nature and Evolution of the Fusion Boundary in FerriticAustenitic Dissimilar Weld Metals; Part 1: Nucleation and Growth". Welding Journal Supplement. P329-337. (1999).

16. Nelson, T., Lippold, J. and Mills, M. "Nature and Evolution of the Fusion Boundary in FerriticAustenitic Dissimilar Weld Metals; Part 2: OnCooling Transformations" .Welding Journal Supplement. P267-277. (2000).

17. Kou, S. and Yang,K."Mechanisms of Macrosegregation Formation near Fusion Boundary in Welds Made with Dissimilar Filler Metals". Welding Journal Vol.86. P308. (2007).

18. Kou, S. and Yang,K. "Fusion-Boundary Macrosegregation in Dissimilar-Filler Welds". ASM International, Materials Park, Ohio, USA. P.329340. (2007).

19. Seok-Jae Leea and Young-Kook Lee. "Effect of Austenite Grain Size on Martensitic Transformation of a Low Alloy Steel". Trans Tech Publications Ltd, Switzerland, Materials Science Forum Vols. 475479 .P. 3169-3172. (2005).

20. Hong-Seok Yang and Bhadeshia, H. "Austenite Grain Size and the Martensite-Start Temperature". Scripta Materialia 60.P493-495. (2009).

21. Prawotoy, Y., Jasmawati1, N. and Sumeru, K."Effect of Prior Austenite Grain Size on the Morphology and Mechanical Properties of Martensite in Medium Carbon Steel". J. Mater. Sci. Technol., 28(5). P 461-466. (2011).

22. American Petroleum Institute. "API -5 L-2PSL specification for pipe line 44th edition" P10. (2008)

23. John, N. and Ronald, E."Review of Dissimilar Metal Welding for the NGNP Helical-Coil Steam Generator". U.S. Department of Energy; Office of Nuclear Energy. Idaho National Laboratory. P9-19. (March 2010).

24. American Welding Committee. "Materials and Applications-Part2; Volume 4 of welding handbook, Eighth edition". American Welding Society. P354355. (2003).

25. Anand, R., Sudha, C., Thomas Paul, V., SAROJA, S. and Vijayalakshmi, M. "Microstructural Changes 
in Grade 22 Ferritic Steel Clad Successively with Ni-Based and 9Cr Filler Metals". Welding Journal; Vol. 89. P56-74. (2010).

26. Anand, R., Sudha, C., Saroja, S., Terrance, A L E. and Vijayalakshmi, M."Simulation of Carbon Diffusion Profile in Dissimilar Weldment of Ferritic Steels using Diffusion Coefficients Evaluated by Den Broeder's Method". Hradec nad Moravicí; METAL. P1-7. (2008). 